\title{
PENERJEMAHAN MANUSKRIP DI LOMBOK: SUATU USAHA UNTUK MEMAHAMI NILAI BUDAYA SASAK
}

\author{
(TRANSLATION OF MANUSCRIPTS IN LOMBOK: AN EFFORT TO \\ UNDERSTAND THE SASAK'S CULTURAL VALUES)
}

\author{
Safoan Abdul Hamid \\ Kantor Bahasa Provinsi Nusa Tenggara Barat \\ Jalan dr. Sujono, Kelurahan Jempong Baru, Sekarbela, Mataram, NTB, Indonesia \\ Pos-el: safoan.hamid@gmail.com
}

Diterima: 14 November 2013; Direvisi: 2 Desember 2013; Disetujui: 3 Desember 2013

\begin{abstract}
Manuscript or codex is one of the valuable heritage artefacts of the ancestors because it enshrines historical trace, knowledge and cultural values of the past. Lombok island is known for its great number of manuscripts stored both in museum and those among society. Hence, it is necessary to preserve the manuscripts physically and non-physically (contents preservation). This paper is aimed at offering an idea that the translation of Sasak's manuscripts is one of the efforts to understand the cultural values of Sasak community. Translating the manuscript's texts is perceived as part of contents preservation. The data of this study is gathered through a field research at Sakra Village, East Lombok where palm leave manuscripts are found. The result of an in-depth interview to the owner of such manuscripts and people around shows the abundance of cultural values contained in that manuscripts such as cultural value on relation of human to God and cultural value on relation of human to the others. Supporting data are obtained through literature study on variety of written references. The data then are analyzed descriptively to develop the theme. However, people could not benefit from that manuscript owing to the language and alphabet barrier. Only few people understand the texts because its language and alphabet are no longer in use among Sasak community. Translation of Sasak's manuscripst had been done but still encounters difficulties in sustainability because government seems to give less attention to the research and translation of manuscript texts as well as the lack of experts in the alphabet used by most Sasak's manuscript which is called "jejawan" alphabet. In conclusion, it is a need for the government to have a division or agency dealing with research and translation of the manuscript and to continue the teaching of "jejawan" alphabet as the local content in primary school.
\end{abstract}

Keywords: translation, manuscript, cultural values, Sasak community

\begin{abstract}
Abstrak
Manuskrip atau naskah kuno merupakan salah satu artefak warisan nenek moyang yang sangat berharga karena di dalamnya tersimpan jejak sejarah, ilmu pengetahuan, dan nilai-nilai budaya masa lalu. Pulau Lombok dikenal menyimpan banyak koleksi manuskrip baik yang tersimpan di museum maupun yang berada di tengah-tengah masyarakat. Oleh karena itu, perlu dilakukan preservasi fisik dan non-fisik manuskrip - preservasi kandungan. Makalah ini bertujuan untuk menawarkan sebuah gagasan bahwa penerjemahan teks manuskrip merupakan salah satu usaha untuk memahami nilainilai budaya masyarakat Sasak. Penerjemahan dianggap sebagai-bagian dari upaya preservasi manuskrip secara non-fisik. Data-data dalam kajian ini dikumpulkan melalui studi lapangan di desa Sakra tempat disimpannya beberapa manuskrip berbahan lontar. Hasil wawancara dengan pemilik manuskrip dan penduduk sekitar menunjukkan bahwa manuskrip-manuskrip tersebut sarat akan nilainilai budaya seperti nilai hubungan manusia dengan Tuhan dan nilai hubungan manusia dengan
\end{abstract}


sesama. Data pendukung dikumpulkan melalui kajian pustaka terhadaap berbagai referensi tertulis. Data-data itu kemudian dianalisis untuk mendukung tema kajian ini. Masyarakat tidak dapat mengambil manfaat dari keberadaan manuskrip itu karena kendala bahasa dan aksara. Hanya segelintir orang yang dapat memahami teksnya karena bahasa dan aksara yang digunakan tidak dipakai lagi di tengah-tengah masyarakat Sasak. Penerjemahan manuskrip Sasak pernah dilakukan tapi tidak ada keberlanjutan disebabkan oleh kurangnya perhatian pemerintah terhadap pengkajian dan penerjemahan manuskrip serta sedikitnya ahli yang memahami bahasa dan aksara manuskrip yang dikenal dengan aksara jejawan. Dapat disimpulkan bahwa pemerintah perlu membentuk bidang atau lembaga yang khusus bertugas untuk mengkaji dan menerjemahkan manuskrip serta melanjutkan pengajaran aksara jejawan sebagai muatan lokal di tingkat sekolah dasar.

Kata kunci: penerjemahan, manuskrip, revitalisasi, nilai budaya, masyarakat Sasak

\section{Pendahuluan}

Manuskrip atau naskah kuno merupakan salah satu artefak warisan budaya Nusantara di masa lalu yang sangat berharga. Manuskrip mengandung rekaman aktifitas nenek moyang, ilmu pengetahuan, dan nilai budaya yang perlu dilestarikan di tengah semakin bobroknya moral dan semakin berkembangnya budaya hedonisme di tengah-tengah masyarakat sekarang. Oleh karena itu, kemampuan memahami kandungan manuskrip sangat penting agar generasi sekarang dapat mengambil manfaat dari kekayaan kandungan nilai manuskrip itu. Dengan memahami isi manuskrip, generasi sekarang diharapkan untuk mengenal dan bangga terhadap budaya sendiri. Pemahaman isi manuskrip terutama yang terkait dengan nilai-nilai budaya dapat menjadi suatu usaha untuk membendung pengaruh negatif arus globalisasi dan westernisasi yang dapat mengubah tatanan nilai dan pola pikir masyarakat sekarang. Namun sayangnya manuskrip yang masih ada sekarang menggunakan bahasa dan aksara yang tidak lagi hidup di masyarakat. Salah satu solusi untuk mengatasi masalah itu adalah dengan menerjemahkan teks manuskrip ke bahasa yang dapat dipahami masyarakat.

Penerjemahan teks manuskrip dapat dipandang sebagai suatu usaha preservasi non-fisik. Preservasi manuskrip bukan hanya sebatas perawatan fisik, tapi yang tidak kalah pentingnya adalah pelestarian isinya.
Banyaknya dan terawatnya manuskrip di museum atau perpustakaan tidak banyak manfaatnya jika pesan teksnya tidak dapat dipahami oleh masyarakat. Dengan diterjemahkannya teks manuskrip ke bahasa yang dapat dipahami masyarakat berarti kandungan teksnya telah terselamatkan.

Makalah ini membahas mengenai usaha untuk memahami nilai-nilai budaya Sasak melalui penerjemahan teks manuskrip yang terdapat di Pulau Lombok. Etnis Sasak adalah penduduk asli Pulau Lombok, Provinsi Nusa Tenggara Barat. Pulau Lombok menyimpan banyak koleksi manuskrip. Bahkan pulau ini dikenal sebagai "laboratorium konservasi" naskah Jawa Kuno dalam persfektif Islam (Rosidi: 2008). Hal itu disebabkan karena sebagian besar manuskrip yang ditemukan di Lombok merupakan saduran dan salinan dari manuskrip yang berasal dari Jawa. Umumnya manuskrip itu berisi ajaran agama Islam, khususnya Tasawuf, dan karya-karya sastra gubahan orang Sasak asli.

Sebagian besar manuskrip di Pulau Lombok terbuat dari daun lontar yang dikenal dengan istilah takepan. Sebagian manuskrip juga menggunakan bahan kertas. Manuskrip-manuskrip itu tersimpan di Museum Negeri Provinsi NTB dan tidak sedikit juga berada di rumah-rumah penduduk. Umumnya manuskrip Sasak menggunakan bahasa reramputan yakni campuran beberapa bahasa seperti Sasak, Bali, Jawa, dan Melayu. Aksara yang 
digunakan adalah aksara Jejawan, yakni turunan dari bahasa Jawa Kuno.

Bahasa dan aksara tersebut sangat sulit dan tidak dipakai lagi di tengah-tengah masyarakat sehingga orang Sasak pun tidak dapat memahami teks manuskrip yang berada di daerahnya. Lebih-lebih manuskrip Sasak terbuat dari bahan lontar yang sangat rentan mengalami kerusakan. Kondisi beberapa naskah lontar (takepan) di desa Sakra, Lombok Timur, sangat memperihatinkan. Kandungan teksnya hanya dipahami oleh pemilik naskah yang umurnya sudah lanjut. Sebelum rusak, manuskrip itu perlu diselamatkan, baik secara fisik dan non-fisik, yakni melalui kegiatan penerjemahan.

\section{Kerangka Teori}

\subsection{Filologi dan Penerjemahan Manuskrip}

Ilmu yang mengkaji manuskrip dikenal dengan filologi. Filologi sebagai ilmu yang berhubungan dengan karya tulis masa lampau dengan anggapan bahwa dalam karya tulis itu terkandung nilai-nilai yang masih relevan dengan kehidupan masa kini. (Baried, 1994:1). Oleh karena itu, di era modern ini kajian filologi bermanfaat untuk menjaga kelestarian budaya nenek moyang serta untuk dapat memahami budaya dan cara pandang mereka. Hasil kerja filologi juga dapat dimanfaatkan oleh para pakar dari berbagai cabang ilmu dan pekerjaan untuk mendalami disiplin masing-masing.

Tahap-tahap yang dilalui dalam kajian filologi adalah inventarisasi naskah, deskripsi naskah, perbandingan naskah, transliterasi dan penerjemahan naskah, dan telaah naskah. Kerja filologi yang sempurna tidak hanya sampai pada tahap inventarisasi dan pembuatan katalog tapi semestinya diikuti dengan transliterasi, penerjemahan, dan publikasi.

Transliterasi adalah penyalinan dengan penggantian huruf dari abjad satu ke abjad yg lain (KBBI, 2002). Dengan kata lain, transliterasi hanya sebatas pengalihan aksara ke aksara yang lainnya, misalnya transliterasi aksara Jawa Kuno, Arab Melayu, atau Sanskerta ke aksara Latin. Hasil transliterasi berupa teks yang menggunakan aksara sasaran dengan tetap mempertahankan bahasa aslinya. Dengan demikian hasil transliterasi teks belum cukup membuat suatu teks naskah dapat dipahami tanpa dilanjutkan dengan proses penerjemahan ke bahasa sasaran yang dapat dipahami masyarakat.

Berbeda dengan transliterasi, penerjemahan bukan sebatas alih aksara atau huruf. Penerjemahan adalah pemindahan suatu amanat dari bahasa sumber ke dalam bahasa sasaran dengan pertama-tama mengungkapkan maknanya dan kemudian gaya bahasanya (Kridalaksana dalam Nababan: 2008). Yang menjadi bahasa sumber $(\mathrm{BSu})$ dalam penerjemahan manuskrip adalah hasil transliterasi dari teks aslinya, sedangkan bahasa asli naskahnya masih dipertahankan. Teks hasil transliterasi itu kemudian diterjemahkan ke bahasa sasaran (BSa) yang masih dipakai oleh masyarakat luas.

\subsection{Konsep Penerjemahan Naskah Kuno}

Sebuah teks digolongkan sebagai teks lama dan memiliki nilai sejarah kalau sudah berumur lebih dari 50 tahun. Masalah yang muncul adalah semakin lama teks semakin kompleks masalah pragmatiknya karena antara TSu dan TSa terdapat "jarak waktu" (temporal distance) yang disertai dengan jarak budaya (Hoed, 2006:32). Teks lama diproduksi dalam konteks budaya yang jauh berbeda dengan konteks budaya saat teks itu diterjemahkan. Peran penerjemahan teks manuskrip sangat penting karena penerjemahan berfungsi menjembatani dua budaya yang berkembang dalam zaman yang berbeda. 
Dalam proses penerjemahan teks, akan ditemukan banyak kendala dan kerumitan kebahasaan. Seorang penerjemah teks naskah harus mengandalkan interpretasi dan pemaknaan seakurat mungkin untuk menghasilkan teks terjemahan yang sedekat mungkin dengan TSu. Dalam proses interpretasi kemungkinan terjadinya perubahan dan penyimpangan makna atau pesan dari teks aslinya. Perubahan makna itu dapat berupa penambahan, pengurangan, dan pembelokan makna teks aslinya yang disebabkan oleh kesalahan interpretasi maupun subjektifitas penerjemah. Sedangkan untuk penerjemahan manuskrip sastra, masalah yang mungkin juga timbul adalah berkurang atau hilangnya keindahan dan gaya bahasa teks aslinya. Oleh karena itu seorang penerjemah manuskrip bukan hanya dituntut handal dalam menerjemahkan kata per kata tapi juga dituntut bersikap netral dalam melakukan interpretasi teks, memiliki latar belakang pemahaman budaya yang luas, dan menguasai gaya bahasa karya sastra.

Hasil yang diharapkan dari kegiatan transliterasi dan penerjemahan manuskrip adalah sebuah publikasi naskah yang berisi hasil transliterasi dan terjemahan di dalam BSa tertentu, baik bahasa Indonesia maupun bahasa asing. Dengan tersedianya publikasi terjemahan, manuskrip bukan lagi berfungsi hanya sebagai benda purbakala tanpa makna namun akan menjadi sumber informasi dan rujukan yang mudah diakses oleh masyarakat. Masyarakat juga akan dengan mudah mengambil manfaat dari kandungan nilai-nilai budaya manuskrip.

Nilai budaya yang terkandung dalam manuskrip tidak terlepas dari konsep nilai budaya yang berkembang saat manuskrip itu ditulis. Konsep nilai budaya bersifat universal dan dapat berlaku lintas zaman. Konsep nilai budaya menurut kerangka Kluckhohn (dalam Koentjaraningrat, 2004:28) dapat digunakan untuk mengenal konsep nilai budaya yang terdapat dalam manuskrip. Konsep itu mencakup lima masalah pokok kehidupan manusia yang terdiri dari hakikat hidup, hakikat karya, hakikat kedudukan manusia dalam ruang waku, hakikat hubungan manusia dengan alam, dan hakikat hubungan dengan sesama.

\section{Metode Penelitian}

Data yang terkumpul di dalam makalah ini merupakan hasil penelitian lapangan di salah satu lokasi sampel tempat tersimpannya manuskrip berbahan lontar, yakni di Desa Sakra, Kecamatan Sakra, Kabupaten Lombok Timur. Selama penelitian lapangan, dilakukan wawancara mendalam dengan informan untuk sekaligus pemilik naskah lontar untuk menggali pesan yang disampaikan dalam teks manuskrip, khususnya kandungan nilai budayanya. Wawancara juga dilakukan dengan informan pendukung yakni penduduk sekitar tempat disimpannya manuskrip. Data-data itu kemudian dipadukan dengan hasil kajian pustaka terhadap berbagai sumber tertulis seperti buku, jurnal ilmiah, laporan penelitian, dan laman internet. Data-data tersebut dianalisis secara deskriptif untuk mendukung tema yang disajikan dalam makalah ini yakni usaha memahami nilai budaya Sasak melalui penerjemahan manuskrip di Lombok.

\section{Pembahasan}

\subsection{Penerjemahan Manuskrip di Masa \\ Lalu}

Di masa lalu, berbagai karya-karya sastra dunia diterjemahkan ke berbagai bahasa yang ada di Nusantara sehingga memperkaya khazanah karya sastra Nusantara. Ketika pulau Jawa memasuki zaman keemasan kebudayaan pada tahun 1.000, karya adiluhung epos India Mahabrata disadur ke dalam bahasa Jawa. Sastra Jawa kuno dalam sejarah sastra dan kebudayaan memiliki peran khas untuk 
mempengaruhi sastra-sastra daerah seNusantara seperti sastra Sunda, Madura, Bali, dan Sasak. Ketiganya memiliki hubungan yang cukup erat dengan tradisi Jawa Kuno karena pemakaian tradisi huruf yang sama. Melalui sastra Jawa, masuklah ke dalam kesusasteraan Melayu cerita-cerita yang diangkat dari Mahabrata dan Ramayana. Berbagai karya sastra Islam Melayu juga disadur dan diterjemahkan dari bahasa Arab, Parsi atau India seperti Hikayat Anbiya, Hikayat Raja Jumjummah, Hikayat Nur Muhammad, Hikayat Zakariya, Hikayat Sama'un, Hikayat Iskandar Zulkarnain (Baried, 1994:87-80).

Peran Sastra Jawa kuno dalam mempengaruhi sastra Nusantara sudah tentu melalui kegiatan penyalinan dan penyaduran atau penerjemahan karya sastra ke bahasabahasa Nusantara termasuk ke bahasa Sasak. Oleh karena itu, tidak mengherankan kalau manuskrip Sasak menggunakan aksara jejawan sebagai turunan aksara Jawa Kuno. Bukti-bukti penerjemahan atau penyaduran tersebut menunjukkan berkembangnya tradisi tulis dan sastra serta penerjemahan karya-karya sastra di masa lalu. Hasil terjemahan tersebut dapat dinikmati dan dimanfaatkan oleh generasi sekarang. Adanya kegiatan penerjemahan juga telah terbangunnya hubungan antarbudaya dan antarnegeri meskipun corak kehidupam masyarakat masa lalu bersifat tradisional.. Sudah tentu yang berperan sebagai penghubung antarbudaya tersebut adalah para penerjemah atau penyadur karya sastra. Melalui penerjemahan pula karya sastra yang semula adalah karya sastra lokal beralih fungsi menjadi karya sastra dunia.

\subsection{Manuskrip di Pulau Lombok}

Pulau Lombok begitu kaya dengan manuskrip. Berdasarkan pendataan Ford Foundation pada tahun 1993 di lima desa pada empat kecamatan di Pulau Lombok ditemukan 632 manuskrip disimpan rumah penduduk. Jumlah manuskrip akan lebih banyak jika lokasi pendataan lebih banyak (Rosidi, 2008). Menurut catatan Morrison (dalam Meij, 2002) Museum Negeri Mataram menyimpan 1.227 manuskrip Sasak tapi kondisi tempat penyimpanannya tidak begitu memadai sehingga kemungkinan untuk rusak cukup besar. Sementara itu, Gedung Kirtya, Singaraja Bali juga menyimpan 107 manuskrip Sasak. Terdapat juga koleksi manuskrip Sasak Engelenberg di Perpustakaan Nasional Republik Indonesia. Sementara itu berbagai koleksi juga disimpan di Leiden, Belanda.

Inventarisasi yang dilakukan oleh tim peneliti Kantor Bahasa Provinsi NTB menemukan manuskrip berbahan lontar (takepan) dan kertas pada tahun 2011 di tiga desa di Pulau Lombok. Di desa Sakra, ditemukan manuskrip Mergasih, Jatiswara, Babad Selaparang, Suluk Sujinah, dan Indarjaya. Semuanya menggunakan aksara jejawan dan gabungan bahasa Kawi, Sansekerta, Bali, dan Sasak. Di lokasi lainnya, ditemukan kitab Suluk, Nur Muhammad, kitab Gagak Mrekum (napsuh), kitab Prudaksina, kitab Nabi Yusuf, kitab Labangkara (bahasa Kawi), kitab Rengganis (bahasa Kawi). Sementara itu, ditemukan juga naskah kuno tulisan tangan berbahan kertas yang secara tersirat berjudul Surat dari Made Karang Asem, Primbon (bahasa Arab).

Kondisi tempat penyimpanan manuskrip di rumah penduduk tersebut sangat memprihatinkan karena kurangnya perawatan. Bahkan beberapa bagian dari manuskrip tersebut sudah rusak.

Salah satu media penyampaian pesan yang terkandung dalam manuskrip Sasak adalah tradisi pepaosan. Pepaosan adalah tradisi pembacaan manuskrip yang terbuat dari bahan lontar (takepan) di sebagian masyarakat Sasak di Lombok. Naskah yang dibaca berbentuk puisi dan prosa yang ditembangkan dengan berbagai irama. 
Kelompok pepaosan kelompok terdiri atas pemaca (pembaca), pujangga (penerjemah, pengulas, penafsir) dan penyokong (pendukung vokal). Pepaosan juga menjadi salah satu media hiburan yang diadakan dalam acara selamatan di beberapa bagian wilayah Pulau Lombok.

Pepaosan menjadi sarana pengungkapan pesan, khususnya nilai budaya, yang dilakukan secara lisan. Namun, seiring berjalannya waktu tradisi ini sedikit demi sedikit mulai ditinggalkan masyarakat. Pesatnya perkembangan ilmu pengetahuan dan teknologi informasi modern serta semakin meleknya masyarakat dengan budaya tulis membuat berbagai tradisi lisan (oral tradition) termasuk pepaosan berkurang peminat. Oleh sebab itu, satu-satunya harapan agar masyarakat mengenal manuskripnya adalah dengan membaca langsung teks terjemahan manuskrip. Untuk itu, di zaman ini peran penerjemah teks manuskrip sangat strategis. Teks manuskrip bukan hanya diterjemahkan ke bahasa Indonesia tetapi juga ke bahasabahasa asing.

\subsection{Nilai Budaya dalam Manuskrip Sasak}

Manuskrip Sasak sangat penting untuk diterjemahkan karena di dalamnya terkandung nilai budaya masa lalu yang masih relevan sampai sekarang. Manuskrip yang ditemukan di Desa Sakra mengandung nilai budaya terkait hakikat hidup dan hakikat hubungan manusia dengan sesama.

\subsubsection{Hakikat Hidup}

Hakikat hidup yang ditemukan dalam manuskrip di Desa Sakra, Lombok Timur terkait dengan hakikat hubungan manusia dengan Tuhan. Salah satu manuskrip berbahan lontar di lokasi itu adalah Jatiswara yang berisi ajaran Islam yakni perpaduan iman, Islam, tauhid, dan makrifat. Ketiga unsur itu adalah inti pokok ajaran Islam. Iman adalah pondasi ajaran Islam. Kuatnya iman sangat menentukan cabang- cabang ajaran Islam yang lain. Sedangkan tauhid adalah konsep pengesaan Tuhan, yakni Tuhan sebagai satu-satunya Zat Pencipta segala sesuatu dan satu-satunya Zat yang berhak disembah. Tauhid adalah refleksi keteguhan iman dan penghambaan murni kepada Sang Pencipta.

Naskah Indarjaya berisi kisah seorang syeikh bernama Sahimerda yang melakukan perjalanan untuk menuntut ilmu selama tujuh hari. Selama dalam perjalanan menuntut ilmu ia tidak pernah meninggalkan shalat lima waktu. Ilmu yang dipelajari ialah ilmu Ushul Tasawuf yang berisi syariat, tarikat, hakikat, makrifat serta nasehatnasehat tentang ibadah shalat. Keempat unsur itu adalah tingkatan-tingkatan dalam ajaran tasawuf. Syariat adalah tahapan awal untuk menuju tarikat, hakikat, dan makrifat. Ajaran Tasawuf yang benar tidak boleh meninggalkan ajaran syariat seperti salat dan ibadah-ibadah lainnya.

Hakikat hubungan dengan Tuhan juga dapat ditemukan dalam manuskrip berbahan lontar Suluk Sujinah. Tokoh utama kisah dalam manuskrip itu bernama Dende Sujinah. Manuskrip itu berisi ajaran tarikat atau Tasawuf. Dalam cerita itu, dikupas tentang hakikat di balik syariat agama Islam seperti shalat lima waktu, haji, dan lain-lain. Hubungan dengan Tuhan tidak akan dicapai tanpa pelaksanaan syariat-syariat yang diperintahkan. Di balik tiap tahapan ibadah, ada hakikat-hakikat tersembunyi, contohnya setiap gerakan salat mulai takbir sampai salam, ternyata ada hakikat tersembunyi.

\subsubsection{Hakikat Hubungan Manusia dengan Sesama}

Hakikat hubungan manusia dengan sesama dapat ditemukan dalam manuskrip Babad Selaparang yang berada di Desa Sakra, Lombok Timur. Babad Selaparang berisi sejarah kerajaan Selaparang dengan rajanya yang bernama Kertabumi serta seorang patih yang bernama Arya Banjar Getas. Raja Kertabumi bersaudara dengan 
Raja Pejanggik yang bernama Datu Merajakusuma. Dalam babad Selaparang diceritakan pengkhianatan Arya Banjar Getas. Terjadilah peperangan antara Kerajaan Selaparang dengan Kerajaan Karang Asem Bali yang membuat Kerajaan Selaparang kemudian takluk.

Berbagai nilai budaya dapat dipetik dari manuskrip babad Selaparang di antaranya persaudaraan, kesetiakawanan, gotong-royong, kesetiaan, kekeluargaan, rela berkorban, dan pengorbanan. Rakyat Lombok waktu itu rela berkorban, setia kepada pemimpinnya, dan berkomitmen untuk mempertahankan kerajaan dari rongrongan musuh. Atas dasar persaudaraan, kerajaan-kerajaan lain yang senasib membantu kerajaan Selaparang untuk mengalahkan musuh.

\subsection{Penerjemahan Manuskrip Sasak}

Deskripsi di atas menjadi bukti bahwa manuskrip Sasak kaya akan muatan nilai budaya yang merupakan kekayaan yang sangat tinggi nilainya. Nilai-nilai budaya itu adalah refleksi dari nilai-nilai yang berkembang pada masyarakat Sasak tempo dulu. Selain itu, keberadaannya juga menjadi penghubung untuk menelusuri jejak pola pikir dan cara pandang orang Sasak. Nilainilai yang positif dapat diambil dan dijadikan pedoman hidup. Oleh sebab itu, beberapa tokoh Sasak sudah mentransliterasi dan menerjemahkan manuskrip Sasak ke bahasa Indonesia, selain penerjemahan yang dilakukan oleh orang asing ke bahasa Inggris.

Beberapa manuskrip telah ditransliterasi dan diterjemahkan dari bahasa Jawa Madya dan bahasa Sasak aksara Jejawan ke bahasa Indonesia. Di antaranya adalah buku naskah Lontar Joarsah (Museum Negeri NTB); Hikayat Indarjaya (Lalu Wacana dkk., Depdikbud, 1994), Babad Lombok (Lalu Gede Suparman, Pusat Pembinaan dan Pengembangan Bahasa,
1994), Babad Praya (Pusat Pembinaan dan Pengembangan Bahasa, 1994), Puspakrama (Lalu Gde Suparman). Kedua tokoh itu sangat berjasa telah mentransliterasi dan menerjemahkan manuskirp Sasak. Namun, sayangnya kini program tersebut tidak berkelanjutan.

Keberadaan manuskrip Sasak juga sangat menarik minat peneliti asing. Th.C. Van der Meij dari Universitas Leiden (2002) yang melakukan transliterasi dan menerjemahkan naskah Puskrema ke bahasa Inggris. Naskah asli manuskrip ini ditemukan di desa Obel-obel, Lombok Timur. Menurut catatan Meij, sebelumnya J.C. Van Eerde juga telah mempublikasikan manuskrip cerita Cilinaya (1906) dan Monyeh (1913). Sementara itu, Hooykaas (1948) telah mempublikasikan koleksi cerita rakyat Sasak. Penerjemahan manuskrip Sasak ke bahasa asing merupakan salah satu instrumen penting untuk memperkenalkan budaya Sasak ke dunia internasional, selain untuk tujuan internasionalisasi karya sastra daerah.

Ada beberapa faktor penyebab program penerjemahan manuskrip Sasak tidak berkelanjutan. Pertama, masih rendahnya perhatian pemerintah akan pentingnya kajian dan penerjemahan manuskrip. Melestarikan manuskrip dianggap sudah memadai dengan cara disimpan di museum atau sampai pada pembuatan katalog. Padahal manuskrip bukan sekadar warisan nenek moyang dalam bentuk fisik semata. Kedua, masih langkanya tenaga ahli atau penerjemah yang menguasai bahasa dan aksara manuskrip (jejawan).

Kendala sumber daya yang menguasai aksara jejawan juga yang menjadi penyebab sulitnya melanjutkan pengajaran aksara ini di sekolah. Padahal, aksara ini sudah diajarkan di beberapa SD dan SMP di Lombok sebagai materi muatan lokal. Hasilnya pun tidak efektif karena 
ruang lingkup pengajaran aksara jejawan baru sebatas pengenalan huruf, belum sampai pada tahapan pemahaman teks yang memungkinkan siswa untuk mampu membaca teks manuskrip. Oleh sebab itu, pengajaran aksara Jejewan sebagai muatan lokal di sekolah perlu hidupkan dan diefektifkan kembali.

Oleh karena itu, pemerintah perlu memberikan perhatian khusus dan dukungan terhadap upaya preservasi manuskrip baik secara fisik dan non-fisk. Penerjemahan teks manuskrip adalah salah satu bentuk preservasi manuskrip secara non-fisik sehingga manuskrip-manuskrip yang ada dapat dipahami maknanya, khususnya yang terkait dengan nilai-nilai budaya. Langkah yang ditempuh oleh pemerintah adalah dengan membentuk suatu bidang, lembaga, atau bahkan badan yang secara khusus bertugas mengkaji dan menerjemahkan manuskrip. Lembaga ini nantinya akan bertugas mengumpulkan, meneliti, mengkaji, menerjemahkan, dan mempublikasikan teks manuskrip. Alternatif lain, Badan Pengembangan dan Pembinaan Bahasa sebagai institusi resmi pemerintah yang bertugas menangani permasalahanpermasalahan bahasa dan sastra, melalui unit kerjanya di tingkat provinsi, menelurkan program untuk menerjemahkan program untuk mengkaji dan menerjemahkan manuskrip. Untuk itu, Kantor Bahasa Provinsi NTB memiliki peran strategis untuk menangani pengkajian dan penerjemahan manuskrip Sasak yang ada di Lombok.

\section{Penutup}

Lombok kaya akan koleksi manuskrip baik yang tersimpan di museum maupun yang masih berada di rumah-rumah penduduk. Beberapa sampel manuskrip Sasak di Pulau Lombok yakni di Desa Sakra, Kecamatan Lombok Timur kondisinya sangat memperihatinkan. Padahal, setelah dilakukan wawancara dengan pemiliknya, manuskrip-manuskrip itu sarat akan nilai-nilai budaya positif yang dapat dijadikan acuan hidup. Nilai-nilai budaya itu terkait hakikat hubungan manusia dengan Tuhan dan hakikat hubungan manusia dengan sesama. Sangat disayangkan, seandainya manuskripmanuskrip tersebut rusak atau hilang, maka hilang pula kandungan isinya. Salah satu solusi untuk menyelamatkan isi kandungan manuskrip adalah dengan kegiatan penerjemahan kandungan manuskrip, disamping preservasi fisik. Dengan diterjemahkannya manuskrip, masyarakat atau para pengkaji bahasa dan sastra dapat memahami pesan yang terkandung di dalam manuskrip, khususnya nilai-nilai budaya luhur yang sangat dibutuhkan oleh generasi muda sekarang untuk membendung dampak negatif dominasi budaya barat. Hal ini menjadi sebuah tantangan bagi pemerintah untuk memperhatikan kajian dan penerjemahan manuskrip Sasak.

\section{Daftar Pustaka}

Astutiningtyas, Ratri. (2006). Revitalisasi Budaya Melalui Pemberdayaan Perpustakaan Nasional RI. Majalah Visi Pustaka.

Barried, Siti Barorah, dkk. (1994). Pengantar Teori Filologi. Yogyakarta: BPPF Seksi Filologi Fakultas Sastra UGM.

Hoed, Benny Hoedoro. (2006). Penerjemahan dan Kebudayaan. Jakarta: Pustaka Jaya.

Rosidi, Akhyar. (2008). Melihat Masa Lalu Orang Sasak. http://terunesasak.blogspot.com/2008/12/meliatmasa-lalu-orang-sasak.html. diakses tanggal 12 November 2013. 
Istanti, Kun Zachrun. (2010). Studi Teks Sastra Melayu dan Jawa. Prodi S2 Ilmu Sastra UGM bekerja sama dengan Penerbit Elmatera. Yogyakarta.

Koentjaraningrat. (2004). Kebudayaan, Mentalitas dan Pembangunan. Jakarta: PT. Gramedia Pustaka Utama.

Meij, Th. C.van der. (2002). Puspakrema. The Netherlands: Research School CNWS, Leiden University.

Nababab, M. Rudolf. 2008. Teori Menerjemah Bahasa Inggris. Yogyakarta: Pustaka Pelajar

Suparman, Lalu Gde. (1994). Babad Lombok. Pusat Pembinaan dan
Pengembangan Bahasa, Departemen Pendidikan dan Kebudayaan. Jakarta.

Tim Peneliti Kantor Bahasa Provinsi NTB. (2011). "Inventarisasi dan Deskripsi Manuskrip Sasak di Pulau Lombok". (Laporan Penelitian). Mataram: Kantor Bahasa Provinsi NTB.

Tim Redaksi. (2002). Kamus Besar Bahasa Indonesia. Jakarta: Balai Pustaka. 